\title{
Virtual Learning and Training Needs in a Peripheral Region of Colombia
}

\author{
Francisco R. Bernal ${ }^{1}$, Nidia Guzmán ${ }^{1}$, Juan M. Andrade ${ }^{2}$ \\ ${ }^{1}$ Universidad de Surcolombiana - Usco, Colombia, \\ ${ }^{2}$ Corporación Universitaria Minuto de Dios - Uniminuto, Colombia
}

\begin{abstract}
The present research shows the relationship between the variables of self-regulation, self-efficacy and academic performance among students of undergraduate academic programs in the virtual modality in the universities of southern Colombia. The research was cross-sectional and quantitative, in which 280 surveys with Likert-type questions were applied and the Structural Equations Model was used to validate the hypotheses with the SPSS - AMOS software. The result was the confirmation of a positive and significant relationship between the study variables, and the strong influence generated by self-regulation and self-efficacy on academic performance is corroborated. Finally, the self-regulation and self-efficacy needs in the training processes are evidenced, in order to ensure a certain level of academic success in virtual higher education.
\end{abstract}

Keywords - Self-regulation, self-efficacy, academic performance, virtual higher education.

\section{Introduction}

Higher education in Colombia has presented exponential growth in the last twenty years, standing out for aspects such as coverage, access and quality.

DOI: $10.18421 /$ TEM94-47

https://doi.org/10.18421/TEM94-47

Corresponding author: Juan M. Andrade,

Corporación Universitaria Minuto de Dios - Uniminuto, Colombia.

Email: jandradenav@uniminuto.edu.co

Received: 07 September 2020.

Revised: 15 October 2020.

Accepted: 20 October 2020.

Published: 27 November 2020.

Updated: 17 February 2021.

(cc) BY-NC-ND (C) 2020 Francisco R. Bernal, Nidia Guzmán \& Juan M. Andrade; published by UIKTEN. This work is licensed under the Creative Commons AttributionNonCommercial-NoDerivs 4.0 License.

The article is published with Open Access at www.temjournal.com
Starting in the new century, access to higher education increased at a significant rate, representing a gross coverage rate that increased from $24.0 \%$ in 2000 to $49.0 \%$ in 2015. During this period, the population enrollment at the undergraduate level rose from 873,079 in 2000 to 2,142,443 in 2014. Much of the increase in enrollment has its genesis in the expansion of quotas for technical and technological education, which went from 152,324 in 2000 to 713,500 in 2014 [1].

In this sense, virtual education, framed within the concept of distance education, has had a significant growth in the last decade, especially linked to the technological revolution, particularly with regard to information technologies and ICT telecommunications and the growth of its infrastructure [2], [3].

For the Ministerio de Educación Nacional [4] distance education arises and is positioned in the social context due to the demands of coverage and quality in education, especially of people who, due to geographic reasons and high access costs, could not enjoy pedagogical and scientific advances.

Likewise, it defines virtual education as education in which the interaction between the actors in the teaching and learning process occurs in a virtual setting or cyberspace. In other words, the teacherstudent relationship is fundamentally based on information technologies and telecommunications [4].

In this regard, there are many questions that arise with regard to distance education, specifically about virtual training, given the novelty and accelerated growth that it has presented, standing out for its benefits in coverage and access, but questioning aspects such as the quality of training and learning.

However, some studies have aimed to demystify virtual education and show its benefits. Martínez and Pascual [5] carried out a study in order to establish a significant relationship between virtual education and critical thinking, analyzing variables such as autonomy and self-regulation, among others, finding a notable link between ICT-supported training and characteristics of students associated with critical thinking. 
On the other hand, there are studies associated with efficiency in education that have generally focused on the primary and secondary level of training. Thus, research such as Iregui, Melo and Ramos [6] on technical efficiency in public and private schools, using stochastic techniques, stand out. In this regard, they find that the variables associated with infrastructure and the students' socioeconomic environment has a positive and significant impact on academic progress. In this regard, this type of study is less frequent in virtual higher education.

Among the most recent trends found in studies associated with virtual higher education is selfregulation. Cerezo et al. [7] conducted studies on programs that promote self-regulation in virtual higher education processes, finding related positive results.

This is due to the questions about the factors of academic success in relation to failures [8] presented by higher education, traditionally neglected in aspects such as these. However, this type of education has to pay special attention to its characteristics, it is essential that the student develop aspects such as perseverance, persistence and use of time [9].

\section{Literature Review}

\subsection{Virtual Learning}

For Careaga \& Contreras [10] virtual learning is a process that is supported by the use of technological resources in which factors such as motivation, conviction and self-regulation, among others, have to converge with greater intensity than in face-to-face training.

Gallego and Martínez [11] claim that virtual training has a series of advantages over face-to-face, such as the use of multimedia tools, easy access to more attractive content, interactivity, access from anywhere and at any time, and immediate feedback.

Finally, they highlight that virtual training can present information in interesting ways; however, it requires elements strongly rooted in people who are active subjects in training as elements of motivation and disposition [12].

\subsection{Self-efficacy in Skills Development}

Self-regulation of learning, especially virtual learning, is essential within the training process since it has a strong relationship with behaviors such as the use of study time and perseverance [13]. However, it is important to approach a definition of the term in order to determine aspects of the study.

For Zimmerman [14], self-regulation is a "process formed by self-generated thoughts, emotions and actions that are planned and adapted cyclically to achieve the achievement of personal goals". In other words, it corresponds to the strategies that the person puts into action when he is in the process of achieving the proposed goals.

In that order of ideas there are different theories that expose the aspects that lead to people's selfregulation. The theory of operant conditioning, the action of self-regulation depends on the perception of the rewards to be obtained, that is, on their probability of obtaining and relative importance for the person [15]. On the other hand, for the phenomenological theory it depends on the need of the person to be updated, in other words, to feel competent and reach the ideal state in which he wishes to find himself [16].

Conversely, the information processing theory, led by Johnson-Laird [17] considers that self-regulation activity depends on the information that the person possesses and is capable of processing to know how to perform at a given moment. However, this theory still has serious gaps in the initial motivation to selfregulate.

For the sociocognitive theory [18] the motivations are circumscribed to personal goals, the perception of self-efficacy and the expectations of result, while the theory of volition adds the importance of keeping the value of the goal active [19].

Likewise, the Vygotskian theory limits it to the desire of the person to improve their self-control and learn to relate to and control the environment. Finally, the constructivist theory focuses on the intrinsic desire of the subject to find answers to her questions and find balance after a cognitive conflict [15].

In summary, Panadero and Tapia [15] affirm that special attention should be paid to the level of training that is being analyzed in order to establish the best strategy to stimulate self-regulation in training. This is due to the fact that it was found that some theories were better adapted to the context of primary education, while others behaved very well in the context of secondary education. Finally, they conclude that the needs of people in the training process should be considered when designing and implementing strategies to promote their selfregulation.

\subsection{Need for self-efficacy}

Self-efficacy is defined as a person's perception of their ability to perform a task in order to achieve an established goal [12], [20]. In this regard, some authors indicate that the definition does not refer to the real capacities of the person but to the capacities that he believes he has, which largely evidences a self-perception [21]. 


\subsection{Academic Performance}

The academic performance of students corresponds to one of the most relevant aspects of the learning process. It is generally not easy to conceptualize it since it is broadly related to academic performance or school performance [22]. Jiménez [23] relates it to the level and domain of knowledge that a student exhibits, which could be evident from the appreciation of her evaluations.

Despite the fact that, for some scholars on the subject, it is simplistic to limit oneself to the results of the students' evaluations to determine academic performance, in the present study these will be adopted as the information regarding academic performance.

\section{Materials and Methods}

The methodology of the study is presented in four parts: the first mentions the type and section of the research; the second part describes the participants in the research and some sociodemographic characteristics; the third part details the study variables and their components; and in the fourth parts the software for the analysis of the information.

\subsection{Approach, Method and Type}

A cross-sectional investigation was carried out since the information was collected in a single moment, correlational since it links the relationship between the variables self-regulation, self-efficacy and academic performance, and quantitative [24], in students of virtual training modalities at the University of Southern Colombia.

\subsection{Population and Sample}

The research was carried out on students, of legal age, belonging to undergraduate academic programs in virtual modality at a university in southern Colombia, in which 280 surveys were applied. The sample was made up of men and women of legal age, the age range ranged between 18 and 32 years. Regarding the level of training, the entire sample corresponded to undergraduate level programs. Regarding sex, $48 \%$ corresponded to men, while $52 \%$ to women. The predominant socioeconomic strata were 1 with $48.5 \%$, strata 2 with $31 \%$, stratum 3 with $19 \%$ and other strata $1.5 \%$.

\subsection{Measurements}

To measure the self-regulation variable, a scale developed by Ortiz [25] and adapted to measure selfregulation processes in virtual learning was used. For all the items, people indicated their perception on a five-point Likert-type scale, where one (1) means totally disagree and four (4) means totally agree. On the other hand, the measurement of the self-efficacy variable was used on the scale in the management of virtual environments, the Computer Self-efficacy Scale (CSE), elaborated and developed by Harrison $\&$ Rainer [26]. For all items, people indicated their perception on a four-point Likert-type scale, where one (1) means very little confidence, two (2) little confidence, three (3) high confidence and (4) total confidence. Finally, the scale of academic achievement will be measured with the average of the grades obtained by the students on a general scale from 1 to 5 .

Table 1. Definition and operation of variables of the questionnaires

\begin{tabular}{|c|c|}
\hline Variable & Dimension \\
\hline \multirow{3}{*}{$\begin{array}{l}\text { Self-regulation } \\
\text { (AR) }\end{array}$} & Complex skills (HC) \\
\hline & Advanced skills (HA) \\
\hline & Elemental skills (HE) \\
\hline \multirow{10}{*}{$\begin{array}{l}\text { Self-efficacy } \\
\text { (AE) }\end{array}$} & Task value (VT) \\
\hline & Self monitoring (AM) \\
\hline & Causal attributions (AC) \\
\hline & Self appraisal (AEV) \\
\hline & Task analysis (AT) \\
\hline & Goal setting (EM) \\
\hline & Metacognitive strategies (EMC) \\
\hline & Motivational strategies (EMT) \\
\hline & Self-satisfaction (AS) \\
\hline & Inferences (IF) \\
\hline $\begin{array}{c}\text { Academic } \\
\text { performance } \\
(\mathrm{RA})\end{array}$ & Average of marks obtained (PN) \\
\hline
\end{tabular}

\section{Source. Own elaboration}

\subsection{Analysis of Data}

In general, a Structural Equation Modeling (SEM) was used to evaluate the relationships and effects between the proposed variables. The SEM is a statistical multivariate analysis technique that allows testing of causal relationships - using quantitative data - based on assumptions or qualitative reflections on the sense of causality [27].

\section{Results and Discussion}

The results of the investigation are presented below. The maximum likelihood estimation method was used, and the analysis was performed with a covariance matrix. The proposed theoretical model was made up of Self-Regulation, Self-efficacy and Academic Performance perceived as latent variables and their respective dimensions and indicators. The hypothesized model obtained a good fit in the data, 
obtaining a significant chi-square $(\chi 2[1328, \mathrm{~N}=$ $250]=1853.643 ; \mathrm{p}<0.00), \mathrm{IFI}=.90, \mathrm{TLI}=.89, \mathrm{CFI}$ $=0.90, \mathrm{GFI}=0.88$. On the other hand, Table 2 shows Cronbach's Alpha for the three proposed variables in the parentheses, showing excellent consistency (Selfregulation, $\alpha=0.87$; Self-efficacy, $\alpha=0.90$; Academic Performance, $\alpha=0.79$ ).

Table 2. Means, standard deviations and correlations of the variables

\begin{tabular}{cccccc}
\hline Variable & M & SD & 1 & 2 & 3 \\
\hline $\begin{array}{c}\text { Self- } \\
\text { regulation } \\
(\text { AR) }\end{array}$ & 3,45 & 0,24 & $(0,87)$ & & \\
\hline $\begin{array}{c}\text { Self-efficacy } \\
(\text { AE) }\end{array}$ & 3,22 & 0,40 & $0,82^{* *}$ & $(0,90)$ & \\
\hline $\begin{array}{c}\text { Academic } \\
\text { performance } \\
(\mathrm{RA})\end{array}$ & 4,1 & 0,56 & $0,85^{* *}$ & $0,88^{* *}$ & $(0,79)$ \\
\hline
\end{tabular}

\section{Source. Own elaboration}

Likewise, a more detailed analysis of the reliability of the instrument dimensions was carried out (see table 3). For the dimensions of the Self-regulation variable, the following were obtained: Complex skills was 0.80, Advanced skills was 0.82 and Elementary skills was 0.91 . On the other hand, for the dimensions of the Self-efficacy variable, the following were obtained: Task value was 0.94, Selfmonitoring was 0.88, Causal attributions was 0.91, Self-assessment was 0.90, Task analysis was 0.87 , Goal setting was 0.88 , Metacognitive strategies was 0.90, Motivational strategies was 0.92, Selfsatisfaction was 0.91, and Inferences was 0.89 . Finally, the Average dimension of grades obtained was 0.79 .

Table 3. Reliability of dimensions

\begin{tabular}{lc}
\hline \multicolumn{1}{c}{ Dimensiones } & Cronbach's alpha \\
\hline Complex skills (HC) & 0,80 \\
\hline Advanced skills (HA) & 0,82 \\
\hline Elemental skills (HE) & 0,91 \\
\hline Task value (VT) & 0,94 \\
\hline Self monitoring (AM) & 0,88 \\
\hline Causal attributions (AC) & 0,91 \\
\hline Self appraisal (AEV) & 0,90 \\
\hline Task analysis (AT) & 0,87 \\
\hline Goal setting (EM) & 0,88 \\
\hline Metacognitive strategies (EMC) & 0,90 \\
\hline Motivational strategies (EMT) & 0,92 \\
\hline Self-satisfaction (AS) & 0,91 \\
\hline Inferences (IF) & 0,89 \\
\hline Average of marks obtained (PN) & 0,79 \\
\hline
\end{tabular}

Source. Own elaboration
Subsequently, the correlations of the study are shown through the structural equation model. All the correlations were in the expected direction and provided preliminary support to the hypotheses raised regarding the strong link that has to exist between self-regulation, self-efficacy and academic performance for the achievement of success in higher education in virtual modality.

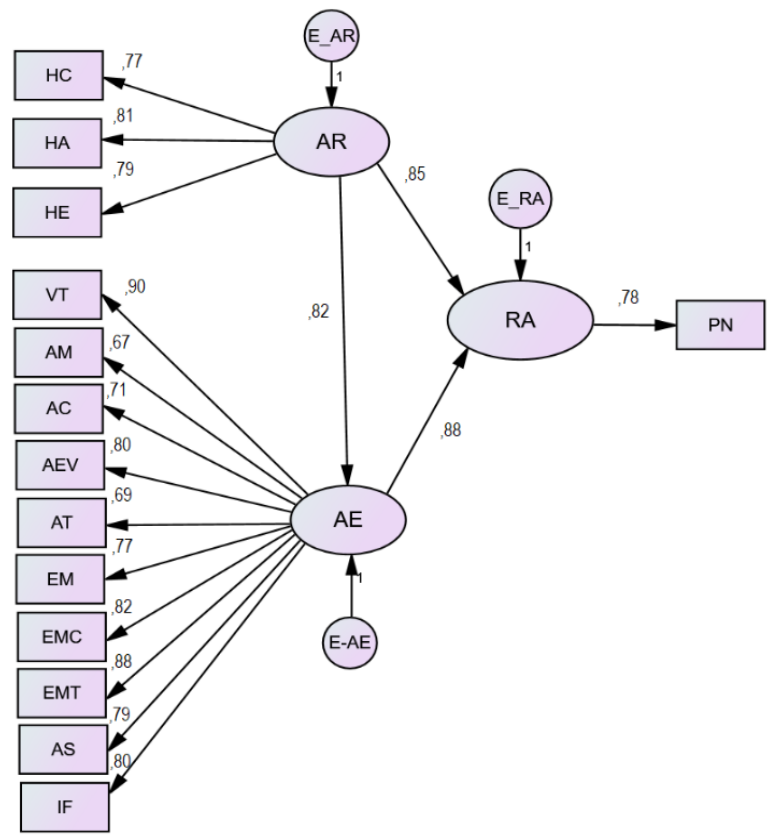

Figure 1. Structural equation model Source. Own elaboration

As can be seen in Figure 1, there is a positive and significant relationship between the Self-regulation variable and Academic Performance: 0.851; $\mathrm{p}<0.00$. From what can be inferred that the more the level of Self-regulation increases, the higher will be the Academic Performance of the students of undergraduate academic programs in the virtual modality in the universities of southern Colombia. Likewise, the relationship between Self-efficacy presents a positive and significant relationship with the Academic Performance reported by the students $(0.879 ; \mathrm{p}<0.00)$. It can be inferred that, in the face of high levels of self-regulation and self-efficacy, the academic performance of students is higher, especially for the virtual training modality that requires a series of more intense practices and behaviors, compared to face-to-face training.

On the other hand, as expected, a highly significant and positive relationship was found between Selfregulation and Self-efficacy $(0.852 ; \mathrm{p}<0.00)$, which denotes a strong link between these variables in the successful training process. 


\section{Conclusions}

In general, a positive and significant relationship between the study variables is confirmed, and the strong influence generated by the self-regulation of students of undergraduate programs in the virtual modality on their academic results is confirmed, that is, certain skills are fundamental for the academic success of virtual training. On the other hand, it was confirmed that self-regulation has a strong link with self-efficacy, and together they largely ensure the performance of the people who are being trained.

Regarding the limitations of the study, it should be mentioned that the data were obtained through a cross-sectional investigation; that is, the data were collected at a specific time and this can give a partial and biased reading of the phenomenon, which could be corrected with a longitudinal investigation. Likewise, an additional effort has to be made in order to include the analyzes; some exogenous and endogenous variables of the training that can affect student performance in the virtual modality, generating a broader and more generous interpretation of the phenomenon.

\section{References}

[1]. Melo-Becerra, L. A., Ramos-Forero, J. E., \& Hernández-Santamaría, P. O. (2017). La educación superior en Colombia: situación actual y análisis de eficiencia. Revista Desarrollo y sociedad, (78), 59111.

[2]. Yong, E. y Bedoya, D. (2016). De la educación tradicional a la educación mediada por TIC: Los procesos de enseñanza aprendizaje en el siglo XXI. Virtual Educa.

[3]. Castillo, É. Y., García, N. N., Corredor, C. M., \& Malaver, C. E. C. (2017). Evolución de la educación superior a distancia: desafíos y oportunidades para su gestión. Revista Virtual Universidad Católica del Norte, (50), 81-105.

[4]. Ministerio de Educación Nacional (2009). Educación Virtual o Educación en Línea. Retrieved from: http://www.mineducacion.gov.co/1621/article196492.html [accessed: 10 June 2020].

[5]. Berruezo, M. Á. M., \& Gómez, I. P. (2013). La influencia de la enseñanza virtual sobre el pensamiento crítico de los profesores en formación. Profesorado. Revista de Currículum y Formación de Profesorado, 17(3), 293-306.

[6]. Iregui, A. M., Melo, L., \& Ramos, J. (2007). Análisis de eficiencia de la educación en Colombia. Revista de Economía del Rosario, 10(1), 21-41.

[7]. Cerezo, F., Sánchez, C., Ruiz, C., \& Arense, J. J. (2015). Roles en bullying de adolescentes y preadolescentes, y su relación con el clima social y los estilos educativos parentales. Revista de Psicodidáctica, 20(1), 139-155.
[8]. Pérez, J. C. N., García, J. A. G. P., Rosario, P., Mourao, R., \& Trigo, J. (2005). SRL Enhancing Narratives: Testas'(Mis) adventures. Academic Exchange Quarterly, 9(4), 73-77.

[9]. Soares, A. P., Almeida, L. S., \& Couñago, M. A. G. (2011). Ambiente académico y adaptación a la universidad: un estudio con estudiantes de $1^{\circ}$ año de la Universidad do Minho. Revista iberoamericana de psicología y salud, 2(1), 99-121.

[10]. Careaga, M., \& Contreras, G. (2006). Incorporación de una plataforma virtual para acceder al aprendizaje: una experiencia de formación on-line, para los docentes de la Universidad San Sebastián. Nova Educa.

[11]. Rodríguez, A. G., \& Caro, E. M. (2003). Estilos de aprendizaje y e-learning. Hacia un mayor rendimiento académico. Revista de Educación a Distancia (RED), (7).

[12]. Rodriguez, A. (2015). Relación entre estilos de aprendizaje, autoeficacia en el manejo de los ambientes virtuales y el aprendizaje virtual del personal administrativo de una universidad privada (Doctoral dissertation, Tesis para optar el título de Maestro en Psicologia). Universidad Católica de Colombia. Colombia).

[13]. Nota, L., Soresi, S., \& Zimmerman, B. J. (2004). Self-regulation and academic achievement and resilience: A longitudinal study. International journal of educational research, 41(3), 198-215.

[14]. Zimmerman, B. J. (2000). La consecución de la autorregulación: Una perspectiva cognitiva social. Manual de autorregulación, 13-40.

[15]. Panadero, E., \& Alonso-Tapia, J. (2014). Teorías de autorregulación educativa: una comparación y reflexión teórica. Psicología educativa, 20(1), 11-22.

[16]. Zimmerman, B.J. (2001). Teorías del aprendizaje autorregulado y el rendimiento académico: una visión general y un análisis. En BJ Zimmerman y DH Schunk (Eds.), Aprendizaje autorregulado y logro académico (Segunda ed., Págs. 1-37). Nueva York: Lawrence Erlbaum Associates.

[17]. Johnson-Laird, P.D. (1988). La computadora y la mente. Harvard University Press, Cambridge, MA.

[18]. Bandura, A. (1997). La auto-eficacia: El ejercicio del control. Nueva York: WH Freeman.

[19]. Corno, L. (2001). Aspectos voluntarios del aprendizaje autorregulado. En BJ Zimmerman y DH Schunk (Eds.), Aprendizaje autorregulado y logro académico (segunda ed., Págs. 191-226). Nueva York: Lawrence Erlbaum Associates.

[20]. Martín, E. G. (2000). Autoeficacia en el mundo laboral. Apuntes de psicología, 18(1), 9-38.

[21]. Soler, H., \& del Mar, M. (2017). ¿ Cómo desarrollar la autoeficacia del estudiantado? Presentación y evaluación de una experiencia formativa en el aula de traducción?. Revista digital de investigación en docencia universitaria, 11(2), 50-74.

[22]. Navarro, R. E. (2003). El rendimiento académico: concepto, investigación y desarrollo. REICE. Revista Iberoamericana sobre Calidad, Eficacia y Cambio en Educación, 1(2). 
TEM Journal. Volume 9, Issue 4, Pages 1681-1686, ISSN 2217-8309, DOI: 10.18421/TEM94-47, November 2020.

[23]. Hernández, M. J. (1994). Competencia social: intervención preventiva en la escuela. Infancia y Sociedad: Revista de estudios, (24), 21-48.

[24]. Hernández, R., Fernández, C. B. P., \& Baptista, P. (2003). Metodología de la Investigación. México DF, México, Editorial Mc Graw Hill.

[25]. Saavedra, B. D. O. (2020). Construcción y validación de una escala para medir estrategias usadas en el aprendizaje autorregulado en estudiantes de bachillerato. Psicogente, 23(43), 1-24.
[26]. Harrison, A. W., \& Rainer Jr, R. K. (1992). The influence of individual differences on skill in end-user computing. Journal of Management Information Systems, 9(1), 93-111.

[27]. Hair, J. F., Anderson, R. E., Tatham, R. L., \& Black, W. C. (1999). Análisis multivariante (Vol. 491). Madrid: Prentice Hall. 